\title{
THE IMPORTANCE OF LOGISTICS SERVICES FOR THE ECONOMICAL EFFICIENCY IN THE GARMENT INDUSTRY
}

\author{
DARIUSZ MILEWSKI, ${ }^{1}$ BEATA MILEWSKA ${ }^{2}$
}

\footnotetext{
1 University of Szczecin, Faculty of Economics and Management of Services, POLAND

e-mail: dariusz.milewski@wzieu.pl

${ }^{2}$ WSB University in Poznań, Faculty of Finance and Banking in Poznań, POLAND

e-mail: beata.milewska1@gmail.com
}

RECEIVED
ACCEPTED
JEL
CLASSIFICATION

KEYWORDS

ABSTRACT
18 January 2018

2 September 2018

L20, L91, M20

global supply chain, efficiency of logistics processes, logistics costs, costs of lost sales, garment industry

The paper deals with the problem of the importance of the performance of logistics processes and services for the economic efficiency of sourcing strategies (local or global) in the garment industry. It presents the results of the research studies conducted by the authors in the Polish companies from the garment industry. Based on the results of the studies the electronic model of a supply chain has been made in order to estimate, what are the structure of the logistics costs what is the share of them in sales. The simulations conducted with the use of the model shown, that in present conditions, the sourcing strategies have strong impact the logistics costs. Yet relatively higher level of logistics costs in global sourcing (from low cost countries) don't make it less profitable than in sourcing locally. However even small change of purchase costs can make global supply chains unprofitable.

\section{Introduction}

Logistics is considered an important factor of economic efficiency of enterprises. The costs of logistics processes (transport, warehousing, inventory management) and logistics services can be high. Not only costs are important but also logistics performance, which influence other areas in enterprises like production or sales. 
So efficiency of logistics influence overall costs of a company and incomes through a level of logistics customer service (e.g. time of delivery, punctuality) and costs of lost sales.

The garment industry is especially confronted with challenges in logistics. The demand in this market is difficult to forecast and many big companies use the strategy of ordering goods in the low costs countries, which are located far from sales markets. The question here arise, why, despite high logistics cost it has been profitable to use the strategy of global sourcing. That's why the intention of the Authors of the paper was to investigate how important in sourcing decisions logistics efficiency is. One of the goal of the study was also to investigate is the structure of logistics costs and their share in incomes and compare them with the results of the studies of other authors.

Based on the results of the studies the electronic model of a supply chain has been made in order to conduct simulations of the economic efficiency of sourcing strategies.

\section{Litepature review}

The share of total costs presented in the literature vary from 7.50 to $17.08 \%$ turnovers (Table 1 ) and depends on a type of activity, a company size, country, what probably depend among others on geographical conditions. According to the data The Establish Davis Logistics Cost and Service Database (Table 2), transport costs are the largest share (3-4\%) in incomes and the total logistics costs stand for $8-9 \%$ of sales.

Table 1. The structure of logistics costs in different countries (\%)

\begin{tabular}{lcccccc}
\hline \multirow{2}{*}{ Country } & \multicolumn{2}{c}{$\begin{array}{c}\text { Logistic costs } \\
\text { of production }\end{array}$} & \multicolumn{5}{c}{ Share in turnover } \\
\cline { 3 - 7 } & in relation to turnover & transport & warehousing & inventories & administration & other \\
\hline Finland & 12.10 & 4.60 & 2.60 & 3.00 & 1.20 & 0.70 \\
USA & 7.50 & 3.79 & 1.73 & 1.79 & 0.19 & \\
Poland & 17.08 & 6.16 & 3.47 & 4.15 & 3.30 & \\
Norway & 14.20 & & & & & \\
\hline
\end{tabular}

Source: own elaboration based on: Solakivi et al. (2015), Ślusarczyk, Kot (2013), Karri, Ojala (2012), Inger, Wiljar (2010).

Table 2. Logistic costs as percent share in sales

\begin{tabular}{lllllll}
\hline \multicolumn{1}{c}{ The type of cost } & 2010 & 2011 & 2012 & 2013 & 2014 & 2015 \\
\hline Transport & 4.08 & 3.79 & 3.44 & 3.66 & 4.43 & 4.62 \\
Warehousing & 1.75 & 1.76 & 1.89 & 2.04 & 1.99 & 2.16 \\
Customer Service & 0.43 & 0.3 & 0.3 & 0.37 & 0.41 & 0.37 \\
Administration & 0.23 & 0.19 & 0.19 & 0.22 & 0.30 & 0.22 \\
Inventory Carrying & 1.79 & 1.73 & 2.05 & 2.11 & 0.22 & 2.19 \\
\hline Total logistics costs & 8.28 & 7.77 & 7.87 & 8.41 & 9.34 & 9.56 \\
\hline
\end{tabular}

Source: Establish Davis Database (2018).

Above data although interesting have some drawbacks. First they are aggregated data.

Second these costs are probably only estimated.

And third the so called "opportunity costs" (costs of capital tied up in inventories and lost sales) are the economic category are not identified in the traditional accounting systems. 
The logistics affect the economic efficiency not only through cost but also through good logistics customer service and, consequently, higher sales and in fact the logistics customer service can be more important than costs optimization for profitability of a company (Stank, Goldsby, Vickery, Savitskie, 2003; Fugate, Mentzer, Stank, 2010).

\section{The economical efficieiency in the garment industry}

Garment business has its own specificity - first of short product lifecycle, high volatility, low predictability (Marufuzzaman, Ahsan, Xing, 2009; Battistoni, Fronzetti Colladon, Mercorelli, 2013; Nenni, Giustiniano, Pirolo, 2013), long production lead time, forecasting errors (Bruce, Daly, Towers, 2004). Commercial success or failure in fashion markets is largely determined by the organisation's flexibility and responsiveness (Rayman, Burns, Nelson, 2011). In fact the difficulties in predicting demand has led big clothing companies like $\mathrm{H} \& \mathrm{M}$ and Zara to focus on the improvement of responsiveness in their supply chains (De Carlo, Tucci, Borgia, 2013).

The organization of the logistics processes in the garment industry depends to a great extend on the geographical localization of production of clothes. The largest Polish clothing companies, such as LPP SA and Redan Capital Group as well as their foreign competitors operating in Poland (eg H \& M or Grupa Inditex) order production mainly in Far East (Bangladesh and China). But for several years there has been a tendency to increase the share of locally or regionally ordered production of clothes.

The Global Fashion Industry's average EBITA was apx. 9.8\% in 2014 (McKinsey \& Company, 2015). The average Retailer's Gross Margins in American companies on clothing are estimated on the level of apx. 47.02\%, and Net Margins - 5\% - 7.6\% in 2013. In 2013, the average net profit margin amongst the 44 largest Apparel \& Accessories Retailers world-wide was 7.6\% (National Retail Federation, 2015). Similar financial results are achieved by Polish clothing companies among by LPP SA (Table 3).

Table 3. Financial results of LPP SA

\begin{tabular}{lccccc}
\hline Years & 2013 & 2014 & 2015 & 2016 & 2017 \\
\hline Sales revenues & 4116302 & 4769288 & 5130353 & 6019046 & 7029425 \\
Own cost of sale & 1707151 & 1976788 & 2387524 & 3085236 & 3335184 \\
\hline Own cost of sale/sales (\%) & 41.5 & 41.4 & 46.5 & 51.3 & 47.4 \\
\hline Gross profit (Loss) on sales & 2409151 & 2792500 & 2742829 & 2933810 & 3694241 \\
Sales costs & 1604796 & 1942937 & 2012420 & 2405007 & 2783033 \\
\hline Cost of sale/sales (\%) & 39.0 & 40.7 & 39.2 & 40.0 & 39.6 \\
\hline Overall costs & 154409 & 205411 & 179247 & 203799 & 241804 \\
Other operating cost & 68116 & 80938 & 72704 & 138007 & 130395 \\
Profit (loss) from operating activities & 615627 & 609103 & 502689 & 226421 & 578434 \\
\hline Operating profit margin (\%) & 15.0 & 12.8 & 9.8 & 3.8 & 8.2 \\
\hline
\end{tabular}

Source: own elaboration based on reports on the materials of the LPP SA Capital Group.

The biggest share of costs were the "own cost of sale" (41.5-47.4\%) and "sales costs" (around 40,0\%). Similar cost and margins structure also occurs in many of other companies listed on the Warsaw Stock Exchange (Table 4). Basing on these data the simulations have been conducted, which show, that even $5 \%$ increase of "costs of sales" have considerable impact on margin netto (reduction 14-56\%). Costs of logistics are included in the "Cost of sales", which are the costs of distribution of goods. 
Table 4. Decrease of the margin as a result of $5 \%$ increase of cost of sales of chosen listed companies from garment industry

\begin{tabular}{lcccc}
\hline \multicolumn{1}{r}{ Name of a company } & Sales revenues & Own cost of sale/sales (\%) & Margin netto (\%) & Reduction of margin (\%) \\
\hline Esotiq \& Henderson SA & 124,224 & 45 & 4.0 & -56.4 \\
Primamoda & 35,838 & 74 & 24.9 & -14.8 \\
Bytom SA & 152,911 & 38 & 8.3 & -23.0 \\
Gino Rossi & 284,748 & 42 & 4.5 & -46.9 \\
Monnari Trade SA & 231,773 & 41 & 9.3 & -22.1 \\
Vistula & 598,602 & 34 & 8.5 & -20.2 \\
LPP & $6,019,046$ & 40 & 3.8 & -53.1 \\
\hline
\end{tabular}

Source: own elaboration on the basis of data from the financial statements of companies

In order to estimate importance of the efficiency of logistics processes and services on the financial performance of companies from garment industry an electronic model of a supply chain has been elaborated by the authors of the paper.

\section{The economical efficiency of supply chains in garment industry}

The model allows to calculate profitability of two strategies: global sourcing (sourcing from countries of low costs of production like Bangladesh) and local sourcing in Poland.

Maladjustment of production volume to demand results in the costs of the lost sales when an actual demand would be higher than the forecasted or when it is lower and some part of the goods have to be sold in outlets for lower prices. The model takes into consideration both of these scenarios.

Data used for calculations were partly collected from companies during a research conducted by the Authors of the paper, from transport and logistics operators, from the scientific literature and publicly available data on rates for logistics services (transport, warehousing).

The data concerning parameters of deliveries have been obtained mainly from LPP SA (joint-stock company). The yearly number of items sold by this company is $14 \mathrm{mln}$ pcs., and daily to a logistics centre in Poland 20-22 containers come from Far East in which there are about 20,000 pieces of clothes per container (Table 5). The yearly incomes in 2017 it was 7 bln PLN, what means that one item has a retail value on average of over 50 PLN.

Two scenarios concerning predictability have been taken into consideration in the model - the actual demand was: 1 - 10\% lower, $2-10 \%$ higher than the forecasted.

The assumptions for the first scenario are in the Table 5. Apart from this it is assumed, that in case of a local supply goods are delivered on a daily basis, and when globally sourced twice a week, but time of a delivery (by ship) -45 days.

Tahle 5. Parameters of purchased goods used for simulations ( $90 \%$ predictability of demand)

\begin{tabular}{lc}
\hline Average retail price (PLN/pcs.) & 55.0 \\
Purchase price in global supply (PLN/pcs.) & 17.0 \\
Purchase price in local supply (PLN/pcs.) & 29.0 \\
No of products in a unit (items/unit) & 20,000 \\
\hline
\end{tabular}

Source: own study based on market data. 


\section{Results}

The results of the simulations in both scenarios (actual demand 10\% lower and 10\% higher than the forecasted) are as follow (Tables 6 and 7):

a) the total logistics costs are much higher in the global supply than in the local one $-13.4 \%$ of sales, when actual demand is lower and $3.7 \%$, when it is higher, while in local supply $-0.5 \%$ in both scenarios;

b) despite this total costs of supply (including logistics and purchase costs) are lower in case of the global supply because the main factor are purchase costs (43.1-53.1\%);

c) the costs of lost sales stand for very big share of total logistics costs in scenario $2(10,0 \%)$, what confirm, that logistics performance and the logistics customer service are very important factor of the economic efficiency, when sales are difficult to predict;

d) on the second place there are costs of transport (about $3 \%$ of sales), which agrees with the results of other authors' research.

They may explain, why despite high logistics costs in global supply chains it is profitable to source in the low costs countries. The costs of production in this countries are so low, that even if actual demand is lower than forecasted $(-10 \%)$ and goods have to be sold at a discounted price this is strategy still will be profitable.

On the other hand however, they also may explain, why presently the production is coming back to Europe and to Poland - even a small increase of the costs of production in the Far East decrease considerably the profitability of this strategy. In case of lower margins, the share of logistics costs is increasing and have greater impact on profits.

It must also be emphasized that simulations have been conducted for two scenarios, in which a actual demand differs from the forecasted demand only by $10 \%$. Demand fluctuations can be even greater and then the impact of the logistics performance on the profitability would also be greater.

Table $\boldsymbol{6}$. Costs of supply of supply strategies

\begin{tabular}{lcccc}
\hline Predictability - actual demand & \multicolumn{2}{c}{$90 \%$} & \multicolumn{2}{c}{$110 \%$} \\
\hline Strategy of supply & local supply & global supply & local supply & global supply \\
\hline Costs (PLN/year) & 1,000 & 1,000 & 1,000 & 1,000 \\
Purchase costs & $3,654,000$ & $2,380,000$ & $4,466,000$ & $2,380,000$ \\
Fees and duties & - & 911,376 & - & 911,376 \\
Lost sales & - & 11,200 & - & 764,400 \\
Transport from a supplier & 9,265 & 199,144 & 11,324 & 199,144 \\
Transport in distribution & 18,529 & 18,529 & 22,647 & 22,647 \\
Inventories & 1,514 & 30,512 & 1,851 & 30,512 \\
Warehousing & 1,902 & 4,235 & 2,082 & 4,235 \\
\hline Total logistics costs & 31,211 & 263,621 & 37,903 & $1,020,938$ \\
\hline Total suppply costs & $3,685,211$ & $3,543,797$ & $4,503,903$ & $3,547,914$ \\
\hline Margin of net profit (\%) & 4.1 & 8.2 & 9.0 & 12.4 \\
\hline
\end{tabular}

Source: own calculations based on the market data. 
Table 7. Share of logistics for different values of goods (\%)

\begin{tabular}{lcccc}
\hline Predictability - actual demand & \multicolumn{2}{c}{90} & \\
\hline Strategy of supply & local supply & global supply & local supply & global supply \\
\hline Purchase costs with fees and duties & 53.1 & 46.8 & 53.1 & 43.1 \\
Lost sales & 0.0 & 0.2 & 0.0 & 10.0 \\
Transport & 0.4 & 3.1 & 0.4 & 2.9 \\
Inventories & 0.0 & 0.4 & 0.0 & 0.4 \\
Warehousing & 0.0 & 0.1 & 0.0 & 0.1 \\
\hline Total logistics costs & 0.5 & 3.7 & 0.5 & 13.4 \\
\hline
\end{tabular}

Source: own calculations based on the market data.

\section{Conclusions}

The conducted simulations confirmed opinions expressed by some authors, that logistics performance is important factor of economic efficiency in the garment industry. Possibility to react quickly to demand in this market plays vital role, more than possibility to decrease logistics costs. This can be a surprise because of the distances are long and value of clothes is low (high share of logistics costs in the value of purchased goods). The explanation are big differences between retail price of clothes and production costs in the low costs countries.

Results of calculations conducted by Authors of the paper partly agrees and partly differs from the ones presented in the literature. It has been confirmed that, if the costs of the lost sales are not included, transport costs are the largest share of total logistics costs. What's more the share of the transport costs is similar to the share of these costs in different publications. The other costs - warehousing and inventory management and lower than in the literature.

The authors of the paper contributed also by estimating possible costs of the lost sales, usually don't identified in the literature.

\section{References}

Battistoni, E., Fronzetti Colladon, A., Mercorelli, G. (2013). Prominent determinants of consumer based brand equity. International Journal of Engineering Business Management, 5 (25), 1-8.

Bruce, M., Daly, L., Towers, N. (2004). Lean or agile: A solution for supply chain management in the textiles and clothing industry? International Journal of Operations \& Production Management, 2 (24), 151-170.

De Carlo, F., Tucci, M., Borgia, O. (2013). Bucket brigades to increase productivity in a luxury assembly line. International Journal of Engineering Business Management, 1, 5-28.

Establish Davis Database (2018). Retrieved from: www.establishinc.com/establish-davis-database.

Fugate, B.S., Mentzer, J.T., Stank, T.P. (2010). Logistics performance: efficiency, effectiveness, and differentiation. Journal of Business Logistics, 1 (31), 1-43.

Inger, B.H., Wiljar, H. (2010). Logistics costs in Norway. Key figures and international comparisons. TØI report 1052, Oslo, 1-112. Retrieved from: https://www.toi.no/publications/logistics-costs-in-norway-key-figures-and-international-comparisons-article 28208-29.html.

Karri, R., Ojala, R. (2012). Measurement of National-Level Logistics Costs and Performance. International Transport Forum Discussion Paper. Retrieved from: https://www.oecd-ilibrary.org/docserver/5k8zvv79pzkk-en.pdf?expires=1547698246\&id=id\&accname=g uest\&checksum=7769D4EE12874F9E81878BBFED17CC1A.

Marufuzzaman, M., Ahsan, K.B., Xing, K. (2009). Supplier selection and evaluation method using Analytical Hierarchy Process (AHP): a case study on an apparel manufacturing organization. International Journal of Value Chain Management, 3 (2), 224-240. 
McKinsey \& Company (2017). The State of Fashion 2017. The Business of Fashion and McKinsey \& Company. Retrieved from: https://www.mckinsey.com/ /media/McKinsey/Industries/Retail/Our\%20Insights/The\%20state\%20of\%20fashion/The-state-offashion-2017-McK-BoF-report.ashx.

National Retail Federation (2015). 2015 Top 250 Global Powers of Retailing. Retrieved from: https://nrf.com/blog/2015-top250-global-powers-of-retailing.

Nenni, M.E., Giustiniano, L., Pirolo, L. (2013). Demand Forecasting in the Fashion Industry: A Review. International Journal of Engineering Business Management, 5 (37), 1-6.

Rayman, D., Burns, D.J., Nelson, C.N. (2011). Apparel product quality: its nature and measurement. Journal of Global Academy of Marketing Science, 21 (1), 66-75.

Ślusarczyk, B., Kot, S. (2013). Logistics Costs Identification In SME In Poland. Advanced Logistic Systems, 1 (7), 91-96.

Solakivi, T., Ojala, L., Laari, S., Lorentz, H., Töyli, J., Malmsten, J., Viherlehto, N. (2015). Finland State of Logistics 2014. University of Turku. Turku School of Economics, Serie E-1. Retrieved from: https://www.utupub.fi/bitstream/handle/10024/117920/ Finland\%20State\%20of\%20Logistics\%202014.pdf?sequence=2\&isAllowed=y.

Stank, T.P., Goldsby, T.J., Vickery, S.K., Savitskie, K. (2003) Logistics service performance: Estimating its influence on market share. Journal of Business Logistics, 1 (24), 27-55.

Cite this article as: Milewski, D., Milewska, B. (2018). The importance of logistics services for the economical efficiency in the garment industry. European Journal of Service Management, 3 (27/2), 299-305. DOI: 10.18276/ejsm.2018.27/2-36. 